\title{
STUDI PENCAMPURAN SERAT ECENG GONDOK SISTEM HOT ROLLED SHEET BC SPESIFIKASI SEKSI-6 : 2010 BINA MARGA
}

\author{
Heru Prasetyo ${ }^{1}$; Samsul Arif ${ }^{2}$ \\ ${ }^{1)}$ Program Studi Teknik Sipil Fakultas Teknik Universitas Islam Lamongan \\ ${ }^{2)}$ Dosen Program Studi Teknik Sipil Fakultas Teknik Universitas Islam Lamongan \\ Email : heruprash@gmail.com; samsularif90an@gmail.com
}

\begin{abstract}
HRS-BC (Hot Roller Sheet) is a type of flexible pavement construction because it uses asphalt as a binder between the aggregates. This study uses water hyacinth as a substitute for cellulose fiber in the mixture of HRS-BC. The purpose of this study is to determine the effect of water hyacinth cellulose fiber in HRS mixture to the Marshall characteristics. This research uses trial and error method, resulting $7.19 \%$ asphalt content to the total aggregate weight with the variation of cellulose fibers are 3\%, 4\%, 5\%, 6\% and 7\%. Marshall Test is performed to determine the effect of adding the cellulose fiber in the mixture to the components of Marshall Properties, for example Marshall Stability, \% of Void Filed With Asphalt (VFWA), \% of Void in The Mix (VIM), Plastic Fatigue (Flow), and Marshall Quotient (MQ).The result of this study is Marshall evaluation where the greatest score is obtained for stability of $1601 \mathrm{~kg}$, flow of 4.60 $\mathrm{mm}$, Quotient Marshall of $375.44 \mathrm{~kg} / \mathrm{mm}$, VMA of 20.45\%, VFWA of $86.79 \%$, and VIM score of $4.19 \%$. It shows that the best cellulose fiber content is $3 \%$ of asphalt level of 7,19\% and has been in accordance with Bina Marga 2010 Division 6 specification and can be used in asphalt mixture of HRS-BC.
\end{abstract}

Keywords : Bina Marga 2010 Division - 6, Hot Rolled Sheets, Marshall Properties, Fibers Sellulosa.

\section{PENDAhULUAN}

Jalan yang aman, nyaman, kuat dan ekonomis akan mempermudah manusia dalam proses pergerakannya. Untuk mewujudkan kondisi jalan berkualitas perlu diberikan lapisan tambah antara tanah dan roda atau lapis paling atas pada badan jalan. Ada beberapa usaha yang dapat dilakukan untuk meningkatkan sifat-sifat fisik aspal sebagai bahan pengikat untuk menghasilkan suatu bahan campuran jalan yang lebih kuat. Salah satu cara mencegah terjadinya kerusakan dini pada perkerasan jalan akibat beban muatan dan pengaruh air adalah dengan meningkatkan mutu aspal sebagai bahan pengikat dari agregat (Andri, et.al.2012)

Cara yang sering digunakan untuk menaikkan mutu aspal adalah dengan menambah bahan adiktif. Salah satunya seperti polimer, plastik, arang atau dikenal dengan aspal modifikasi. Pemberian bahan tambah polimer diharapkan memberikan penambahan pada sifat-sifat fisik aspal seperti kepekaan terhadap stabilitas yang lebih besar dari aspal konvensional atau aspal dengan penetrasi 60/70. Untuk memperbaiki kinerja campuran agregat beraspal dapat dilakukan dengan memodifikasi sifat-sifat fisik aspal, khususnya penetrasi dan titik lembeknya, dengan menggunakan bahan tambahan sehingga diharapkan bisa mengurangi kepekaan aspal terhadap temperatur dan keelastisannya (Sukirman,1999) .

mempermudah manusia dalam proses pergerakannya. Untuk mewujudkan kondisi jalan berkualitas perlu diberikan lapisan tambah antara tanah dan roda atau lapis paling atas pada badan jalan. Ada beberapa Cara yang sering digunakan untuk menaikkan mutu aspal adalah dengan menambah bahan adiktif. Salah satunya seperti polimer, plastik, arang atau dikenal dengan aspal modifikasi. Pemberian bahan tambah polimer diharapkan memberikan penambahan pada sifat-sifat fisik aspal seperti kepekaan terhadap stabilitas yang lebih besar dari aspal konvensional atau 
aspal dengan penetrasi 60/70. Untuk memperbaiki kinerja campuran agregat beraspal dapat dilakukan dengan memodifikasi sifat-sifat fisik aspal, khususnya penetrasi dan titik lembeknya, dengan menggunakan bahan tambahan sehingga diharapkan bisa mengurangi kepekaan aspal terhadap temperatur dan keelastisannya (Sukirman, 1999) .

Dalam penelitian ini, menggunakan bahan aditif Selulosa yang berasal dari serat Eceng Gondok, tanaman ini merupakan suatu gulma air yang sekali tumbuh dan berkembang ternyata mempunyai kandungan serat selulosa cukup tinggi, yakni berkisar $60 \%$. Hal ini sangat memungkinkan bahwa Eceng Gondok berpotensi sebagai bahan dasar pembuatan selulosa yang kedepannya dapat diaplikasikan ke arah yang beragam. Mengingat di daerah Lamongan banyak dijumpai tanaman Eceng Gondok yang saat ini masih sebagian kecil dimanfaatkan sebagai bahan kerajinan. Untuk itu dalam penelitian ini akan mencoba memanfaatkan Eceng Gondok sebagai bahan campuran Campuran Aspal Panas. Penelitian ini dilakukan untuk mengetahui pengaruh penggunaan Serat Enceng Gondok sebagai bahan pengganti serat selulosa pada Campuran Aspal Panas LATASTON (Hot Rolled Sheet) BC. Diharapkan hasil dari pengujian penelitian dapat memenuhi atau dapat meningkatkan kualitas dari aspal tersebut sehingga dapat meningkatkan umur rencana jalan raya.

Berdasarkan permasalahan yang diajukan dalam penelitian ini, maka tujuan yang hendak dicapai yaitu untuk mengetahui secara umum pengaruh penambahan Serat Eceng Gondok terhadap karakteristik campuran aspal panas pada Sistem Hot Rolled Sheet BC yang mengacu pada Spesifikasi Bina Marga 2010 Seksi-6.

\section{METODE PENELITIAN}

Penelitian inidilakukan di Laboratorium Progam Studi Fakultas Teknik Sipil, Universitas Islam Lamongan. Jl. Veteran No.53 A Lamongan. menggunakan Metode Trial And Error. Dan mengacu pada Spesifikasi Departemen Pekerjaan Umum
Bina Marga Devisi-6 (2010). Untuk Diagram Alir Penelitian dapat dilihat pada Gambar 1.

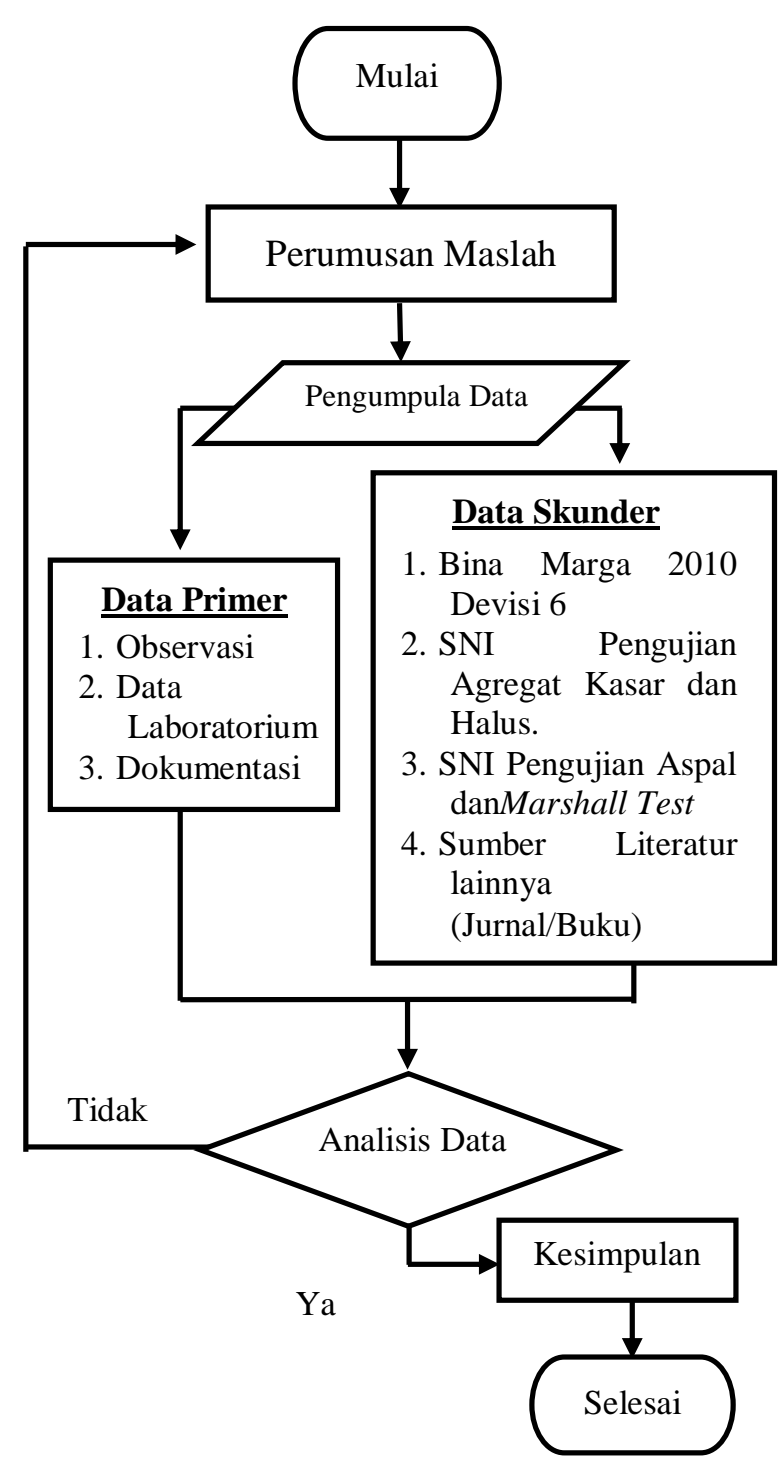

Gambar 1 Diagram Alir / Flowchart

\section{HASIL DAN PEMBAHASAN Pemeriksaan Agregat}

Bahan ageregat yang digunakan pada penelitian ini, yang berasal dari PT. Cahaya Indah Madyah Pratama terdiri dari agregat kasar dan halus. Untuk agregat kasar atau batu pecah yang digunakan yaitu pasokan langsung dari batu pecah Mojokerto. Hasil pemeriksaan karakteristik agregat dapat dilihat pada Tabel dibawah ini : 
Tabel 4 : Hasil Pemeriksaan Agregat

\begin{tabular}{|c|c|c|c|}
\hline No. & Jenis pengujian & Hasil & Syarat \\
\hline \multirow[t]{5}{*}{1.} & Agregat Kasar & & \\
\hline & $\begin{array}{l}\text { Berat Jenis } \\
(B u l k)\end{array}$ & $2,51 \mathrm{Gr} / \mathrm{cc}$ & $\geq 2,5$ \\
\hline & Berat jenis SSD & $2,55 \mathrm{Gr} / \mathrm{cc}$ & $\geq 2,5$ \\
\hline & $\begin{array}{l}\text { Berat Jenis } \\
\text { Semu }\end{array}$ & $2,62 \%$ & $\geq 2,5$ \\
\hline & Penyerapan air & $1,65 \%$ & $\leq 3,0$ \\
\hline \multirow[t]{5}{*}{2.} & Agregat Halus & & \\
\hline & $\begin{array}{l}\text { Berat Jenis } \\
(B u l k)\end{array}$ & $2,56 \mathrm{Gr} / \mathrm{cc}$ & $\geq 2,5$ \\
\hline & Berat jenis SSD & $2,61 \mathrm{Gr} / \mathrm{cc}$ & $\geq 2,5$ \\
\hline & $\begin{array}{l}\text { Berat Jenis } \\
\text { Semu }\end{array}$ & $2,68 \%$ & $\geq 2,5$ \\
\hline & Penyerapan air & $1,79 \%$ & $\leq 3,0$ \\
\hline
\end{tabular}

Dari Tabel 4 diatas keseluruhan hasil hasil pengujian baik itu pengujian agregat kasar, dan agregat halus didapatkan bahwa agregat yang akan dipakai memenuhi spesifikasi Bina Marga 2010 Devisi 6 dan standar pengujian menurut SNI .dan memenuhi persyaratan sebagai bahan campuran HRS-BC

\section{Pemeriksaan Aspal}

Jenis aspal yang digunakan dalam penelitian ini adalah aspal minyak penetrasi 60/70 yang diperoleh dari PT. Cahaya Indah Madya Pratama. Hasil pemeriksaan karakteristik aspal disajikan dalam Tabel sebagai berikut :

Tabel 5 : Hasil Pemeriksaan Aspal

\begin{tabular}{clcc}
\hline No. & JenisPemeriksaan & Hasil & Syarat \\
\hline 1. & Penetrasi, 100 & 67 & $60-79$ \\
2. $25^{\circ} \mathrm{C}, 5$ detik & TitikLembek & 49,5 & $48{ }^{\circ} \mathrm{C}-58^{\circ} \mathrm{C}$ \\
3. & TitikNyala & 329 & Min. $200^{\circ} \mathrm{C}$ \\
4. & TitikBakar & 334 & Min. $300^{\circ} \mathrm{C}$ \\
6. & Beratjenis & 1,0209 & Min. 1,00 \\
\hline \multicolumn{2}{l}{ Sumber : Hasil Penelitian, 2018} & &
\end{tabular}

Pada Tabel 5. diatas hasil pemeriksaan aspal AC 60/70. menunjukan Secara umum hasil tersebut Telah Memenuhi ketentuan yang disyaratkan dalam Spesifikasi Umum Bina Marga 2010 Devisi 6 sebagai bahan penyusun campuran beraspal HRS-BC.

\section{Gradasi Campuran Agregat}

Setelah melakukan pengujian masingmasing agregat dapat diketahui apakah gradasi agregat campuran memenuhi syarat atau tidak memenuhi syarat. Dalam pengujian gradasi agregat campuran menurut Spesifikasi Bina Marga 2010 seksi-6 telah memenuhi syarat, maka dapat dilanjutkan untuk perhitungan rancangan proporsi agregat campuran Hotmix HRS-BC. Gradasi Campuran dapat dilihat pada Tabel 6.

Tabel 6 :Analisa Bleeding Gradation Combination

\begin{tabular}{|c|c|c|c|c|c|c|c|c|c|}
\hline \multirow{2}{*}{$\begin{array}{c}\begin{array}{c}\text { Ukuran } \\
\text { ayakan }\end{array} \\
\text { Inch }\end{array}$} & \multicolumn{2}{|c|}{$\begin{array}{c}\text { Coarse } \\
\text { Aggregate }\end{array}$} & \multicolumn{2}{|c|}{$\begin{array}{c}\text { Medium } \\
\text { Aggregate }\end{array}$} & \multicolumn{2}{|c|}{$\begin{array}{c}\text { Fine } \\
\text { Aggregate }\end{array}$} & \multirow{2}{*}{ Gradasi } & \multirow{2}{*}{ Medium } & \multirow{2}{*}{$\begin{array}{c}\text { Spesifi } \\
\text { kasi }\end{array}$} \\
\hline & $\begin{array}{c}100 \\
\%\end{array}$ & $\begin{array}{c}47,62 \\
\%\end{array}$ & $\begin{array}{c}100 \\
\%\end{array}$ & $\begin{array}{c}30,95 \\
\%\end{array}$ & $\begin{array}{c}100 \\
\%\end{array}$ & $\begin{array}{c}21,43 \\
\%\end{array}$ & & & \\
\hline $3 / 4 "$ & 100 & 47,62 & 100 & 30,95 & 100 & 21,43 & 100 & 100 & 100 \\
\hline $1 / 2 "$ & 95 & 45,24 & 95 & 29,40 & 100 & 21,43 & 96,07 & 95 & $90-100$ \\
\hline $3 / 8 "$ & 77,5 & 36,91 & 77,5 & 23,99 & 100 & 21,43 & 82,32 & 77,5 & $65-90$ \\
\hline no.8 & 45 & 21,43 & 45 & 13,93 & 45 & 9,64 & 45 & 45 & $35-55$ \\
\hline no. 30 & 25 & 11,91 & 25 & 7,74 & 25 & 5,36 & 25 & 25 & $15-35$ \\
\hline no. 200 & 5,5 & 2,62 & 5,5 & 1,70 & 5,5 & 1,18 & 5,5 & 5,5 & $2-9$ \\
\hline PAN & 0,00 & 0 & 0,00 & 0 & 0,00 & 0 & 0 & 0 & 0 \\
\hline
\end{tabular}

Sumber : Hasil Perhitungan, 2018 
Sedangkan untuk kurva gradasi agregat gabungan untuk campuran Lataston HRS-BC dapat dilihat pada Gambar 2 berikut ini :

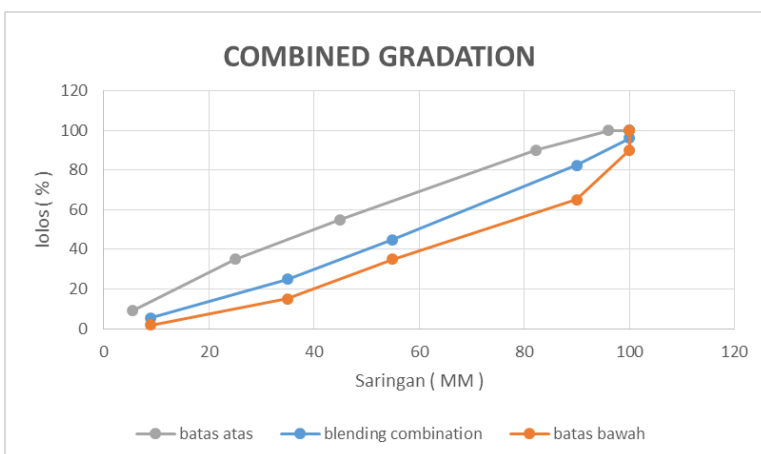

Gambar 2 Gradasi Campuran HRS-BC Sumber : Hasil Perhitungan, 2018

\section{Perhitungan Kadar Aspal Optimum Perkiraan}

Perhitungan kadar aspal optimum perkiraan didasarkan pada hasil pengujian analisis saringan agregat yang telah dilakukan. Untuk menghitung kadar aspal optimum diperoleh dari perhitungan sebagai berikut :

Kadar Aspal

$=0,035 \times \mathrm{CA}+0,045 \times \mathrm{FA}+0,18 \times \mathrm{F}+\mathrm{K}$

$=0,035 \times 55+0,045 \times 39,5+0,18 \times 5,5+2,5$

$=7,19 \%$
$\mathrm{CA}=$ agregat kasar tertahan saringan No.8

$\mathrm{FA}=$ Total agregat halus lolos saringan No.8 dan tertahan No. 200

$\mathrm{F}=$ Filler agregat halus lolos saringan No. 200

$\mathrm{K}=$ Nilai konstanta sekitar $0,5-1,0$ untuk (AC) dan 2,0 - 3,0 untuk (HRS)

\section{Hasil Pengujian Marshall Test}

Pengujian Marshall Test dilakukan bertahap sesuai dengan tujuan penelitian, yakni pertama dilakukan untuk mengetahui kadar aspal yang digunakan apakah sudah memenuhi syarat dan kedua untuk mengetahui pengaruh penambahan serat selulosa dalam campuran terhadap nilai-nilai Marshall Properties yaitu stabilitas Marshall (Marshall Stability), Rongga Dalam Campuran (Void In The Mix / VIM), Persentase Rongga Terisi Aspal (Void Filed With Asphalt / VFWA), Rongga dalam agregat (Void In Mineral Aggregate), Kelelahan Plastis (Flow), Kepadatan Campuran (Density) dan Marshall Quotient (MQ). untuk Perhitungan Marshall Test Dapat Dilihat Pada Lampiran C.1, dan hasil pengaruh penambahan serat eceng gondok terhadap nilai-nilai Marshall Properties Dapat Dilihat Pada Tabel 7.

Tabel 7 : Hasil pengujian Marshall Test Dengan Penambahan Serat Selulosa Eceng Gondok

\begin{tabular}{cccccccc}
\hline $\begin{array}{c}\text { Selulosa } \\
(\boldsymbol{\%})\end{array}$ & Density & $\begin{array}{c}\text { Stabilitas } \\
(\mathbf{K g})\end{array}$ & $\begin{array}{c}\text { VFWA } \\
(\mathbf{\%})\end{array}$ & VIM $(\boldsymbol{\%})$ & $\begin{array}{c}\text { VMA } \\
(\boldsymbol{\%})\end{array}$ & $\begin{array}{c}\text { Flow } \\
(\mathbf{m m})\end{array}$ & $\begin{array}{c}\text { MQ } \\
(\mathbf{K g} / \mathbf{m m})\end{array}$ \\
\hline 0 & 2,18 & 1.610 & 71,66 & 4,89 & 21,44 & 4,23 & 380,60 \\
3 & 2,21 & 1.601 & 76,28 & 4,19 & 20,45 & 4,27 & 375,44 \\
4 & 2,26 & 1.601 & 85,38 & 2,21 & 18,66 & 4,30 & 372,33 \\
5 & 2,26 & 1.592 & 86,79 & 2,09 & 18,41 & 4,37 & 364,73 \\
6 & 2,25 & 1.591 & 85,86 & 2,71 & 18,79 & 4,47 & 356,30 \\
7 & 2,23 & 1.590 & 80,47 & 3,79 & 19,55 & 4,60 & 345,70 \\
\hline Spesifikasi & - & $>800$ & $>68$ & $4,0-6,0$ & $>18$ & $>3$ & $>250$ \\
\hline Pemadatan & & & & & & & \\
\hline Kadar Aspal & & & $7,19 \%$ & & & \\
\hline Sumber : Hasil Perhitungan, 2018 &
\end{tabular}


Tabel 8 : Hasil Model Regresi pengujian Marshall Test Dengan Penambahan Serat Selulosa Eceng Gondok

\begin{tabular}{cccccccc}
\hline $\begin{array}{c}\text { Selulosa } \\
(\boldsymbol{\%})\end{array}$ & Density & $\begin{array}{c}\text { Stabilitas } \\
(\mathbf{K g})\end{array}$ & $\begin{array}{c}\text { VFWA } \\
(\mathbf{\%})\end{array}$ & VIM $(\boldsymbol{\%})$ & $\begin{array}{c}\text { VMA } \\
(\mathbf{\%})\end{array}$ & $\begin{array}{c}\text { Flow } \\
(\mathbf{m m})\end{array}$ & $\begin{array}{c}\text { MQ } \\
(\mathbf{K g} / \mathbf{m m})\end{array}$ \\
\hline 0 & 2,18 & 1.610 & 71,66 & 4,89 & 21,44 & 4,23 & 380,60 \\
3 & 2,20 & 1.601 & 76,26 & 4,20 & 20,46 & 4,26 & 375,44 \\
4 & 2,21 & 1.601 & 85,35 & 2,25 & 18,71 & 4,29 & 372,36 \\
5 & 2,13 & 1.592 & 86,72 & 2,21 & 18,57 & 4,34 & 364,83 \\
6 & 1,93 & 1.591 & 85,74 & 3,01 & 19,17 & 4,41 & 356,55 \\
7 & 1,56 & 1.589 & 80,28 & 4,45 & 20,37 & 4,50 & 346,23 \\
\hline Spesifikasi & - & $>800$ & $>68$ & $4,0-6,0$ & $>18$ & $>3$ & $>250$ \\
\hline Pemadatan & & & & & & & \\
\hline Kadar Aspal & & & $7,19 \%$ & & & \\
\hline
\end{tabular}

Sumber : Hasil Perhitungan, 2018

Tabel 9 :Penelusuran Model Regresi Pengaruh Penambahan Serat Eceng Gondok Terhadap Marshall Properties Campuran

\begin{tabular}{|c|c|c|}
\hline Marshall Properties & Model Perumusan Regresi & $\mathbf{R}^{2}$ \\
\hline Stability Marshall & $\begin{aligned} \mathrm{y}= & -0,2439 \mathrm{x} 5+5,0091 \mathrm{x} 4-37,402 \mathrm{x} 3+119,75 \mathrm{x} 2-140,98 \mathrm{x} \\
& +1609,6\end{aligned}$ & 1 \\
\hline$V F W A$ & $\begin{array}{l}y=-0,093 \times 5+2,0139 x 4-16,294 x 3+57,706 \times 2-71,78 x \\
+71,662\end{array}$ & 1 \\
\hline VIM & $\begin{array}{l}y=0,0159 \times 5-0,3619 x 4+3,0773 \times 3-11,363 \times 2+14,646 x \\
+4,8875\end{array}$ & 1 \\
\hline$V M A$ & $\begin{array}{l}y=0,0132 \times 5-0,3001 \times 4+2,5523 \times 3-9,4276 x 2+12,019 x \\
+21,438\end{array}$ & 1 \\
\hline Density & $\begin{array}{l}y=-0,0004 \times 5+0,0083 \times 4-0,0709 \times 3+0,2617 \times 2-0,3337 x \\
+2,181\end{array}$ & 1 \\
\hline Flow & $y=-0,0003 x 4+0,0051 x 3-0,0204 x 2+0,0336 x+4,2333$ & 1 \\
\hline Marshall Quotient & $\begin{array}{l}y=-0,0532 \times 5+1,1228 \times 4-8,6895 \times 3+28,252 \times 2-34,276 x \\
+380,6\end{array}$ & 1 \\
\hline
\end{tabular}

Sumber : Hasil Perhitungan, 2018

\section{Stabilitas Marshall ( Marshall Stability )}

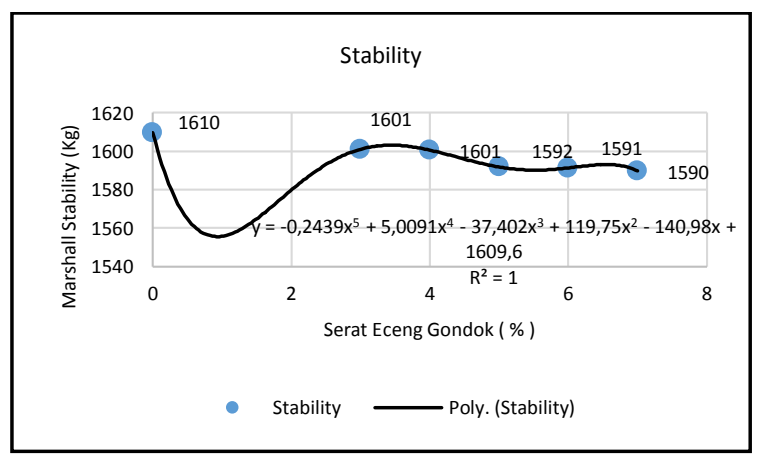

Gambar 3Hubungan Marshall Stability

Dengan Serat Eceng Gondok Sumber : Hasil Penelitian, 2018

Pada Gambar 3. Penambahan serat selulosa dengan variasi $3 \%, 4 \%, 5 \%, 6 \%$ dan
7\% dari berat campuran pada kadar aspal optimum, ternyata secara umum Menunjukan Penurunan Nilai Stabilitas Seiring Dengan Kenaikan Kadar Serat Selulosanya, hal ini dikarenakan penambahan kadar serat selulosa yang terlalu tinggi dan kadar aspal yang tinggi dapat menyebakan terjadinya Bleeding, dan mengurangi kohesi antara aspal dan agregat. Penambahan kadar Serat Selulosa Eceng Gondok yang terlalu tinggi akan membuat campuran cenderung tidak stabil dan rentan terhadap Deformasi Plastis. dari Hasil Penambahan Serat Selulosa Eceng Gondok sebesar 3\% sampai 7\%, menunjukkan Nilai stabilitas telah memenuhi syarat Sesuai dengan spesifikasi Bina Marga 2010 Devisi-6 yaitu lebih dari $800 \mathrm{~kg}$. 


\section{Rongga Dalam Campuran Void In The Mix ( VIM)}

Penambahan serat selulosa dengan variasi $3 \%, 4 \%, 5 \%, 6 \%$ dan $7 \%$ dari berat campuran pada kadar aspal optimumPersentase Void In The Mix menurun sampai batas optimum yaitu pada variasi serat selulosa Eceng Gondok 5,0 \% kemudian mengalami kenaikan dengan semakin bertambahnya variasi kadar serat selulosa Eceng Gondok yang ditambahkan.

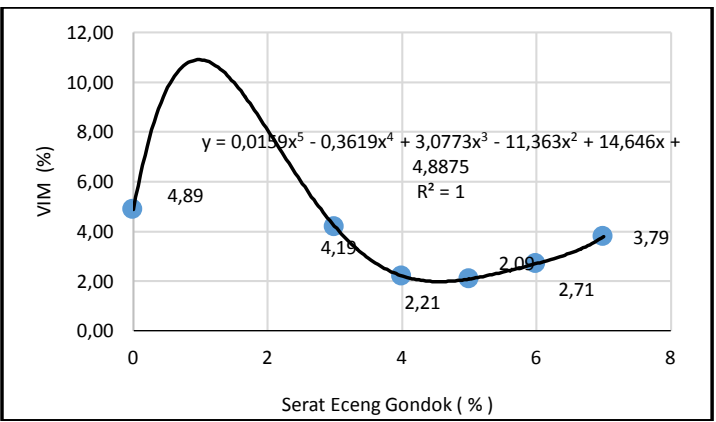

Gambar 4Hubungan Void In The Mix Dengan Serat Eceng Gondok Sumber : Hasil Penelitian, 2018

Pada Gambar Diatas.Dari hasil pengujian maka Penambahan Serat Selulosa Eceng Gondok sebesar 3,0 \% telah memenuhi spesifikasi dan untuk variasi $4,0 \%$ sampai 7,0 $\%$ Belum dapat memenuhi spesifikasi yang telah ditentukan sesuai dengan spesifikasi Bina Marga 2010 Devisi-6.Nilai VIM yang diijinkan antara 4,0 \% sampai dengan 6,0\%.

\section{Rongga dalam agregat Void In Mineral Aggregate (VMA)}

Penambahan serat selulosa dengan variasi $3 \%, 4 \%, 5 \%, 6 \%$ dan $7 \%$ dari berat campuran pada kadar aspal optimum, diketahui nilai Void In Mineral Aggregate menurun sampai batas optimum yaitu pada variasi 5,0 \%kemudian mengalami kenaikan dengan semakin bertambahnya variasi kadar serat selulosa Eceng Gondok yang ditambahkan, Hal ini disebabkan karena penambahan kadar serat Eceng Gondok membuat ruang yang tersedia untuk menampung volume aspal dan volume rongga udara yang diperlukan dalam campuran semakin sedikit. Nilai VMA yang diizinkan lebih dari $18 \%$.

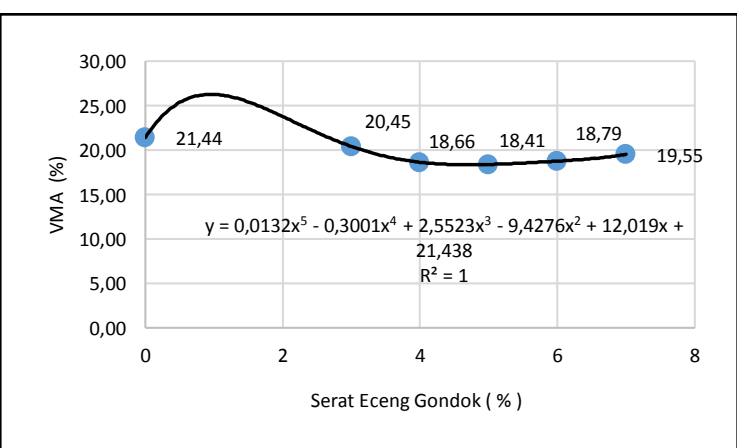

Gambar 5Hubungan Void In Mineral Aggregate Dengan Serat Eceng Gondok Sumber : Hasil Penelitian, 2018

Pada Gambar Diatas. Dari hasil di atas maka Penambahan Serat Selulosa Eceng Gondok sebesar 3,0\% sampai 7,0\% secara umum telah memenuhi spesifikasi yang telah ditentukan sesuai dengan spesifikasi Bina Marga 2010 Devisi-6.

\section{Rongga Terisi Aspal Void Filled With Asphalt ( VFWA )}

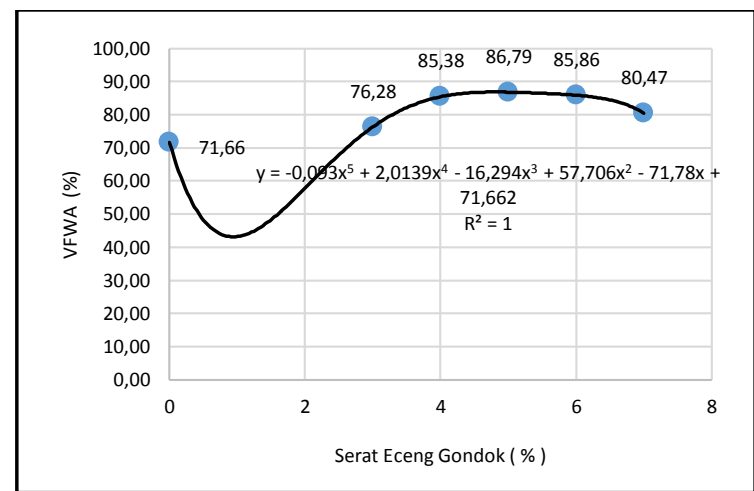

\section{Gambar 6 Hubungan Void Filled With \\ Asphalt Dengan Serat Eceng Gondok Sumber : Hasil Penelitian, 2018}

Pada Gambar Diatas,Penambahan serat selulosa dengan variasi $3 \%, 4 \%, 5 \%, 6 \%$ dan $7 \%$ dari berat campuran pada kadar aspal optimum, menunjukkan bahwa semakin bertambah variasi Serat Selulosa Eceng Gondok yang digunakan, menyebabkan nilai Void Filled With Asphalt / VFWA meningkat sampai batas optimum yaitu pada variasi 5,0 $\%$ kemudian mengalami penurunan dengan semakin bertambahnya variasi kadar serat selulosa Eceng Gondok yang ditambahkan.Hal ini disebabkan karena kadar Serat Selulosa Eceng Gondok yang ada menyerap aspal dan mengisi rongga lebih banyak.Nilai VFWA yang diizinkan yaitu lebih dari $68 \%$. Dari hasil di atas maka 
Penambahan Serat Selulosa Eceng Gondok sebesar $3 \%$ sampai $7 \%$ telah memenuhi spesifikasi yang ditentukan sesuai dengan spesifikasi Bina Marga 2010 Devisi-6. .

\section{Kepadatan Campuran ( Density )}

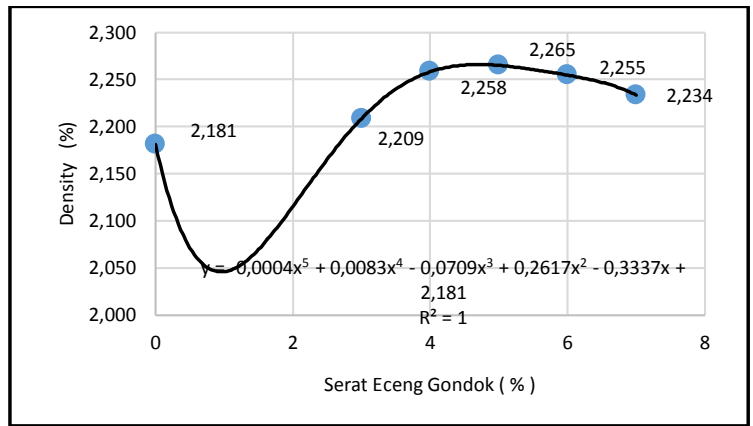

Gambar 8Hubungan Density Dengan Serat Eceng Gondok

Sumber : Hasil Penelitian, 2018

Penambahan serat selulosa dengan variasi $3 \%, 4 \%, 5 \%, 6 \%$ dan $7 \%$ dari berat campuran pada kadar aspal optimum, menunjukkan Semakin bertambahnya variasi kadar serat selulosa Eceng Gondok yang ditambahkan.ternyata nilai Density campuran HRS-B (Hot Rolled Sheet) cenderung meningkat sampai batas optimum yaitu pada variasi 5,0\% kemudian mengalami penurunan dengan semakin bertambahnya variasi kadar serat selulosa Eceng Gondok yang ditambahkan. Hal ini disebabkan setiap penambahan kadar aspal maka rongga antar butiran agregat masih bisa terisi aspal, sehingga campuran menjadi semakin rapat.

\section{Kelelehan Plastis ( Flow )}

Penambahan serat selulosa dengan variasi $3 \%, 4 \%, 5 \%, 6 \%$ dan $7 \%$ dari berat campuran pada kadar aspal optimum, Menunjukkan bahwa nilai flow yang diperoleh cenderung mengalami kenaikan. Hal ini disebabkan karena penambahan Serat Selulosa Eceng Gondok dan kadar aspal menyebabakan peningkatan nilai penetrasi yang menyebabkan campuran cenderung menjadi lebih fleksibel terhadap pembebanan lalu lintas. Nilai flow yang diijinkan Lebih dari $3,0 \%$.

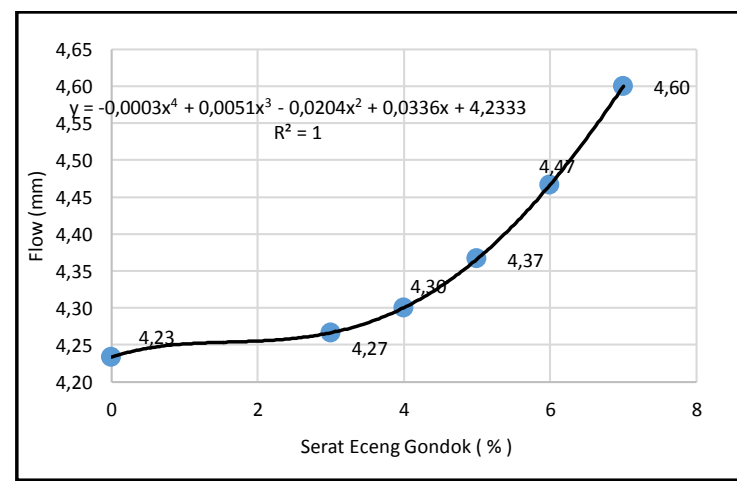

Gambar 7 Hubungan Flow Dengan Serat Eceng Gondok Sumber : Hasil Penelitian, 2018

Pada Gambar Diatas, maka Penambahan Serat Selulosa Eceng Gondok sebesar $3,0 \%$ sampai $7,0 \%$ memenuhi spesifikasi yang telah ditentukan sesuai dengan spesifikasi Bina Marga 2010 Devisi-6

\section{Marshall Quotient ( MQ)}

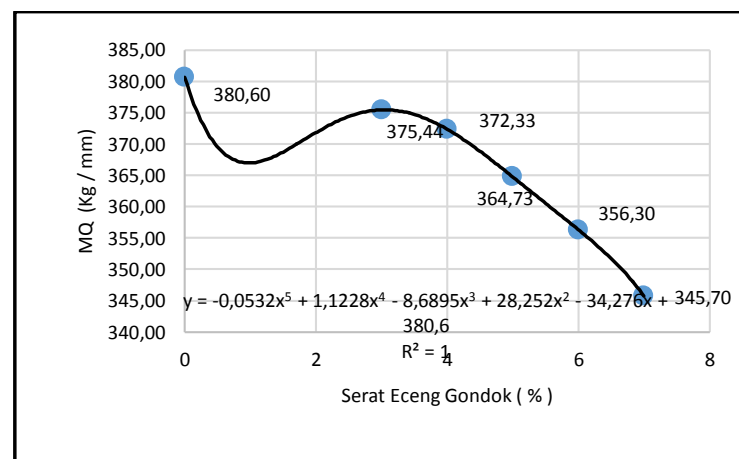

Gambar 9Hubungan Marshall Quotient Dengan Serat Eceng Gondok Sumber : Hasil Penelitian, 2018

Penambahan serat selulosa dengan variasi $3 \%, 4 \%, 5 \%, 6 \%$ dan $7 \%$ dari berat campuran pada kadar aspal optimum, menunjukkan bahwa nilai MQ cenderung akan semakin kecil seiring dengan bertambahnya Serat Selulosa Eceng Gondok. Pada kadar serat $3 \%$ sampai dengan $7 \%$ terhadap kadar aspal 7,19 \% telah memenuhi spesifikasi yang disyaratkan sesuai dengan spesifikasi Bina Marga 2010 Devisi-6 yaitu lebih dari $250 \mathrm{~kg} / \mathrm{mm}$.

\section{Proporsi Kadar Serat Eceng Gondok Optimum}

Berdasarkan hasil pengujian dan perhitungan dengan Penelusuran Model Persamaan Polynomial terhadap masingmasing karakteristik Marshall campuran 
HRS-BC. kemudian dibuat grafik hubungan pengaruh penggunaan variasi Serat Eceng Gondok terhadap masing-masing karakteristik Marshall, sehingga didapat kadar Serat Selulosa Eceng Gondok optimum pada campuran HRS - BC. Dari hasil tersebut didapatkan Titik Tengah dan diperoleh Kadar Serat Selulosa Optimum adalah $3 \%$ dan Telah Memenuhi Spesifikasi Bina Marga 2010 Devisi 6. Untuk lebih jelasnya dapat dilihat pada Gambar 10 berikut ini.

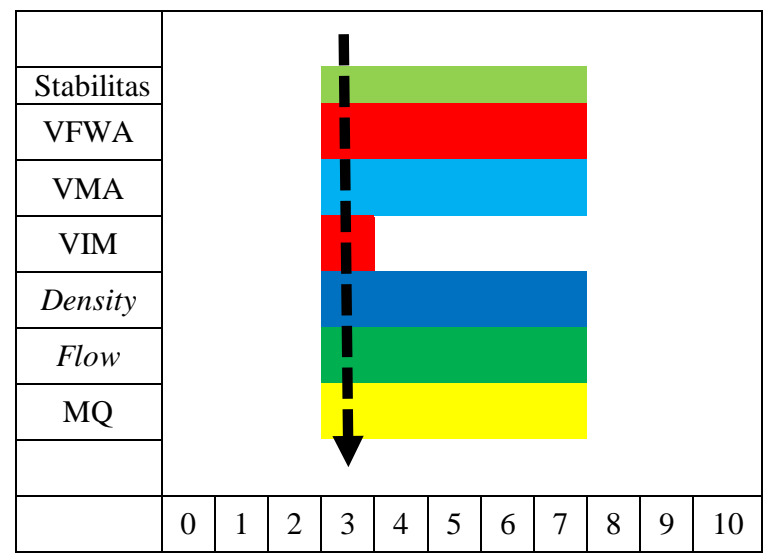

Gambar 10Kadar Serat Eceng Gondok Sumber : Hasil Penelitian, 2018

\section{KESIMPULAN DAN SARAN}

\section{Kesimpulan}

Dari Hasil pemeriksaan dan analisis karakteristikMarshall dimana nilai terbesar diperoleh untuk Stabilitas $1601 \mathrm{~kg}$, Flow 4,60 mm, Quotient Marshall 375,44 kg/mm , VMA $20,45 \%$.VFWA $86,79 \%$, dan nilai VIM 4,19 \%. Hasil ini menunjukkan bahwa serat selulosa dapat meningkatkan mutu aspal dan dapat digunakan dalam campuran Aspal HRS-BC.

Berdasarkan hasil Marshall Properties dari 5 variasi yang digunakan diperoleh Kadar Serat Selulosa Eceng Gondok optimum yang terbaik adalah 3\% dari kadar Aspal 7,19\% dan telah sesuai pada spesifikasi Bina Marga 2010 Divisi 6

\section{Saran}

Pelaksanaan penelitian memerlukan
tenaga-tenaga yang berpengalaman, mempunyai ketelitian yang cukup serta peralatan yang mungkin menggunakan sistem penggerak motorik dan digital sehingga validitas data lebih baik.
Untuk mengetahui lebih banyak fungsi dari serat selulosa sebaiknya dilakukan penelitian lebih mendetail terhadap karakteristik campuran lainnya disamping nilai-nilai Marshall Properties-nya, atau jika dipandang perlu dapat pula diterapkan pada sistem aspal panas yang lain.

\section{DAFTAR PUSTAKA}

Andri, et.al.2012. Pengaruh Penggunaan Kapur Sebagai Bahan Pengisi (Filler) Terhadap Karakteristik Campuran Beton Aspal Lapis Aus (AC-WC). Jurnal Rekayasa dan Manajemen Transportasi Volume II No. 2, Juli 2012 Hal. 87 104. Jurusan Teknik Sipil Universitas Tadulako, Palu

Bina Marga., 2010. Spesifikasi Umum Direktorat Jenderal Bina Marga Edisi 2010 Divisi 6. Kementrian Direktorat Jendral Pekerjaan Umum Indonesia.

BSSNI, 2002. SKSNI 13-6717-2002. Tata Cara Penyiapan Benda Uji Dari Contoh Agregat

BSSNI, 2008. SK SNI 1970-2008. Cara Uji Berat JenisDan Penyerapan Air Agregat Halus

BSSNI, 2008. SKSNI 1969-2008. Cara Uji Berat Jenis Dan Penyerapan Air Agregat Kasar

BSSNI, 2011. SKSNI 2433-2011. Cara uji titik nyala dan titik bakar aspal dengan alat cleveland open cup

BSSNI, 2011. SKSNI 2441-2011. Tentang Cara Uji Berat Jenis Aspal Keras

BSSNI, 2011. SKSNI 2456-2011. Tentang Cara Uji Penetrasi Aspal

Sukirman., 1999. Perkerasan Lentur Jalan Raya.Penerbit NOVA. Bandung 